\title{
PUSAT PERADABAN ISLAM ABAD PERTENGAHAN: Kasus Bayt al Hikmah
}

\author{
M. Mußhlis Fahruddin \\ Fakultas Tarbiyah UIN Maulana Malik Ibrahim Malang. Jalan Gajayana No.50 Malang, Telp. 0341- \\ 3174661.08563625347, e-mail: Mukhlis_fahruddin@yahoo.com
}

\begin{abstract}
Science had gotten progression rapidly in Abbasiyah period, it showed by practiced of books translating activity in many languages, out of arabic language and emergence Bayt al-Hikmah as center of civilization and progression in science. Bayt al-Hikmah had formed not only as library but also as translating center, discussion center, and research center. All progression in Abbasiyah period is not far from possessor support and high appreciation which they give to any master in the way to developed science. Because of that, there were various science and specialist present and it makes intellectual tradition in development of Abbasiyah period significant and dynamic.
\end{abstract}

Key words: Abbasiyah period, bayt al-hikmah, science

\section{Pendahuluan}

Dalam sejarah peradaban Islam, kerajaan yang cukup menonjol dalam sejarah keemasaan Islam adalah kerajaan Umayyah di Spanyol yang berlangsung kurang lebih delapan abad (711-1492) dan kerajaan Abbasiyah yang berpusat di Bagdad yang berlangsung selama kurang lebih lima abad 
(750-1258 M). (Langgulung, 2004: 71). Dua tempat ini mewakili kejayaan negara Islam di Timur dan juga Barat. Kondisi masyarakat pada masa Abbasiyah mempunyai kesadaran yang tinggi akan ilmu, hal ini ditunjukan dengan masyarakat yang sangat antusias dalam mencari ilmu, penghargaan yang tinggi bagi para ulama, para pencari ilmu, tempat-tempat menuntut ilmu, banyaknya perpustakaan-perpustakaan pribadi yang dibuka untuk umum dan juga hadirnya perpustakaan Bayt al Hikmah yang disponsori oleh khalifah pada waktu yang membantu dalam menciptakan iklim akademik yang kondusif. Tak heran jika kita menemukan tokoh-tokoh besar yang lahir pada masa ini. Tradisi intelektual inilah yang seharusnya kita contoh, sebagai usaha sadar keilmuan kita dalam mengejar ketertinggalan dan segera lepas dari keterpurukan. Dalam makalah ini penulis hanya membatasi kepada pembahasan seputar tradisi intelektual pada masa Abbasiyah dengan perpustakaan yang sangat berperan pada masa ini yaitu Bayt al Hikmah, bagaimana peran lembaga Bayt al Hikmah dalam pengembangan keilmuan, faktor-faktor yang mempengaruhi dan apa saja tradisi keintelektualan yang terjadi pada masa tersebut (Abbasiyah).

\section{Sekilas Daulah Abbasiyah}

Khilafah Abbasiyah merupakan kelanjutan dari khilafah Umayyah, dimana pendiri dari khilafah ini adalah keturunan al Abbas, paman Nabi Muhammad yaitu Abdullah al Saffah ibn Muhammad ibn Ali ibn Abdullah ibn al Abbas. Selama dinasti ini berkuasa, pola pemerintahan yang diterapkan berbeda-beda sesuai dengan perubahan politik, sosial dan budaya. Berdasarkan perubahan pola pemerintahan dan politik itu, para sejarawan biasanya membagi masa pemerintahan Bani Abbas menjadi lima periode (Amin, 2004: 106):

1. Periode Pertama (132 H/750 M-232 H/847 M), disebut periode pengaruh Persia pertama.

2. Periode Kedua (232 H/847 M-334 H/945 M), disebut periode pengaruh Turki pertama.

3. Periode Ketiga (334 H/945 M - 447 H/1055 M), masa kekuasaan dinasti Buwaih dalam pemerintahan khilafah Abbasiyah. Periode ini disebut juga 
masa pengaruh Persia kedua.

4. Periode Keempat (447 H/1055 M-590 H/1194 M), masa kekuasaan dinasti Bani Seljuk dalam pemerintahan khilafah Abbasiyah; biasanya disebut juga dengan masa pengaruh Turki kedua.

5. Periode Kelima (590 H/1194 M-656 H/1258 M), masa khalifah bebas dari pengaruh dinasti lain, tetapi kekuasaannya hanya efektif di sekitar kota Bagdad.

Pada periode pertama pemerintahan Bani Abbas mencapai masa keemasannya. Secara politis, para khalifah betul-betul tokoh yang kuat dan merupakan pusat kekuasaan politik sekaligus agama. Di sisi lain, kemakmuran masyarakat mencapai tingkat tertinggi. Periode ini juga berhasil menyiapkan landasan bagi perkembangan filsafat dan ilmu pengetahuan dalam Islam. Namun setelah periode ini berakhir, pemerintahan Bani Abbas mulai menurun dalam bidang politik, meskipun filsafat dan ilmu pengetahuan terus berkembang. Walaupun dasar-dasar pemerintahan Abbasiyah diletakkan dan dibangun oleh Abu al Abbas dan Abu Ja'far al Manshur, tetapi puncak keemasan dari dinasti ini berada pada tujuh khalifah sesudahnya, yaitu:

1. Al Mahdi (775-785 M)

2. Al Hadi (775-786 M)

3. Harun al Rasyid (786-809 M)

4. Al Ma'mun (813-833 M)

5. Al Mu'tashim (833-842 M)

6. Al Wasiq (842-847 M)

7. Al Mutawakkil (847-861 M).

Popularitas daulat Abbasiyah mencapai puncaknya di zaman khalifah Harun al Rasyid (786-809 M) dan puteranya al Ma'mun (813-833 M). Masa pemerintahan Harun al Rasyid yang berkuasa selama 23 tahun itu merupakan permulaan zaman keemasan bagi sejarah dunia Islam belahan timur. Seperti halnya masa pemerintahan Emir Abdulrahman II (206-238 H/822-852 M) di Cordova merupakan permulaan zaman keemasan dalam sejarah dunia Islam belahan Barat (Sou'yb, 1977: 102). 
Khalifah Harun al Rasyid memanfaatkan kekayaannya untuk keperluan sosial, misalnya rumah sakit, lembaga pendidikan dokter, dan farmasi didirikan. Pada masanya sudah terdapat paling tidak sekitar 800 orang dokter. Di samping itu, pemandian-pemandian umum juga dibangun. Kesejahteraan sosial, kesehatan, pendidikan, ilmu pengetahuan, dan kebudayaan serta kesusastraan berada pada zaman keemasannya (Zuhairini, 1997: 96). Lebihlebih lagi dengan adanya lembaga keilmuan yaitu Bayt al Hikmah. Pada masa inilah negara Islam menempatkan dirinya sebagai negara terkuat dan tak tertandingi. Al Ma'mun, pengganti al Rasyid, dikenal sebagai khalifah yang sangat cinta kepada ilmu. Pada masa pemerintahannya, penerjemahan buku-buku asing digalakkan. Untuk menerjemahkan buku-buku Yunani, ia menggaji penerjemah-penerjemah dari penganut agama lain yang ahli. Ia juga banyak mendirikan sekolah, salah satu karya besarnya yang terpenting adalah pembangunan Bayt al Hikmah, pusat penerjemahan yang berfungsi bagaikan perguruan tinggi dengan perpustakaan yang besar dan tempat berkumpul untuk berdiskusi. Pada masa al Ma'mun inilah Baghdad mulai menjadi pusat kebudayaan dan ilmu pengetahuan. Al Mu'tashim, khalifah berikutnya (833-842 M), memberi peluang besar kepada orang-orang Turki untuk masuk dalam pemerintahan, keterlibatan mereka dimulai sebagai tentara pengawal. Tidak seperti pada masa daulat Umayyah, dinasti Abbasiyah mengadakan perubahan sistem ketentaraan. Praktek orang-orang muslim mengikuti perang sudah terhenti. Tentara dibina secara khusus menjadi prajurit-prajurit profesional. Dengan demikian, kekuatan militer dinasti Bani Abbas menjadi sangat kuat.

\section{Kehidupan Intelektual}

Kehidupan intelektual di zaman dinasti Abbasiyah diawali dengan berkembangnya perhatian pada perumusan dan penjelasan panduan keagamaan terutama dari dua sumber utama yaitu al Quran dan Hadits. Dari kedua sumber ini lalu muncullah berbagai keilmuan lainnya. Ilmu-ilmu al Quran dan ilmu-ilmu Hadits adalah dua serangkaian seri pengetahuan yag menjadi pokok perhatian dan fokus perhatian waktu itu. Perhatian itu bisa dilihat dengan banyaknya kitab yang ditulis untuk menjelaskan al Quran. 
Dari gambaran di atas Bani Abbasiyah pada periode pertama lebih menekankan pembinaan peradaban dan kebudayaan Islam daripada perluasan wilayah. Inilah perbedaan pokok antara Bani Abbas dan Bani Umayyah. Sebagaimana diuraikan di atas, puncak perkembangan kebudayaan dan pemikiran Islam terjadi pada masa pemerintahan Bani Abbas. Akan tetapi, tidak berarti seluruhnya berawal dari kreativitas penguasa Bani Abbas sendiri Sebagian di antaranya sudah dimulai sejak awal kebangkitan Islam. Dalam bidang pendidikan, misalnya, di awal kebangkitan Islam, lembaga pendidikan sudah mulai berkembang. Ketika itu, lembaga pendidikan terdiri dari dua tingkat:

1. Maktab/Kuttab dan masjid, yaitu lembaga pendidikan terendah, tempat anak-anak mengenal dasar-dasar bacaan, hitungan dan tulisan; dan tempat para remaja belajar dasar-dasar ilmu agama, seperti tafsir, hadits, figh dan bahasa.

2. Tingkat pendalaman. Para pelajar yang ingin memperdalam ilmunya, pergi keluar daerah menuntut ilmu kepada seorang atau beberapa orang ahli dalam bidangnya masing-masing. Pada umumnya, ilmu yang dituntut adalah ilmu-ilmu agama. Pengajarannya berlangsung di masjid-masjid atau di rumah-rumah ulama bersangkutan. Bagi anak penguasa pendidikan bisa berlangsung di istana atau di rumah penguasa tersebut dengan memanggil ulama ahli ke sana. Lembaga-lembaga ini kemudian berkembang pada masa pemerintahan Bani Abbas, dengan berdirinya perpustakaan dan akademi. Perpustakaan pada masa itu lebih merupakan sebuah universitas, karena di samping terdapat kitab-kitab, di sana orang juga dapat membaca, menulis dan berdiskusi (Maryam, 2003: 126). Perkembangan lembaga pendidikan itu mencerminkan terjadinya perkembangan dan kemajuan ilmu pengetahuan. Hal ini sangat ditentukan oleh perkembangan bahasa Arab, baik sebagai bahasa administrasi yang sudah berlaku sejak zaman Bani Umayyah, maupun sebagai bahasa ilmu pengetahuan.

Kemajuan diraih paling tidak, dipengaruhi beberapa hal diantaranya, terjadinya asimilasi antara bangsa Arab dengan bangsa-bangsa lain yang lebih dahulu mengalami perkembangan dalam bidang ilmu pengetahuan. 
Pada masa pemerintahan Bani Abbas, bangsa-bangsa non-Arab banyak yang masuk Islam. Asimilasi berlangsung secara efektif dan bernilai guna. Bangsa-bangsa itu memberi saham tertentu dalam perkembangan ilmu pengetahuan dalam Islam. Pengaruh Persia, sebagaimana sudah disebutkan, sangat kuat di bidang pemerintahan. Di samping itu, bangsa Persia banyak berjasa dalam perkembangan ilmu, filsafat, sastra serta karya-karya dari Persia juga diterjemahkan (Nakosteen, 1996: 36). Pengaruh India terlihat dalam bidang kedokteran, ilmu matematika dan astronomi. Sedangkan pengaruh Yunani masuk melalui terjemahan-terjemahan dalam banyak bidang ilmu, terutama filsafat. Tradisi yang paling berpengaruh dalam menciptakan tradisi keilmuan yang kondusif adalah gerakan penerjemahan. Gerakan terjemahan berlangsung dalam tiga fase.

Fase pertama, pada masa khalifah al Manshur hingga Harun al Rasyid. Pada fase ini yang banyak diterjemahkan adalah karya-karya dalam bidang astronomi dan manthiq. Fase kedua berlangsung mulai masa khalifah al Ma'mun hingga tahun $300 \mathrm{H}$. Buku-buku yang banyak diterjemahkan adalah dalam bidang filsafat dan kedokteran. Fase ketiga berlangsung setelah tahun $300 \mathrm{H}$, terutama setelah adanya pembuatan kertas. Bidang-bidang ilmu yang diterjemahkan semakin meluas. Pengaruh dari kebudayaan bangsa yang sudah maju tersebut, terutama melalui gerakan terjemahan, bukan saja membawa kemajuan di bidang ilmu pengetahuan umum, tetapi juga ilmu pengetahuan agama. Dalam bidang tafsir, sejak awal sudah dikenal dua metode penafsiran, pertama, tafsir bi al-ma'tsur, yaitu interpretasi tradisional dengan mengambil interpretasi dari Nabi dan para sahabat. Kedua, tafsir bi al ra'yi, yaitu metode rasional yang lebih banyak bertumpu kepada pendapat dan pikiran, daripada hadits dan pendapat sahabat.

Dalam perkembangan pemikiran keilmuan keislaman. kita mengenal imam-imam mazdhab hukum yang empat, mereka semua hidup pada masa pemerintahan Abbasiyah yaitu; Imam Abu Hanifah (700-767 M), Imam Malik (713-795 M), Imam Syafi'i (767-820 M) Imam Ahmad Ibnu Hanbal (780-855 M). Hal yang sama berlaku pula dalam bidang sastra. Penulisan Hadits, juga berkembang pesat pada masa Bani Abbas. Hal itu mungkin terutama disebabkan 
oleh tersedianya fasilitas dan transportasi, sehingga memudahkan para pencari dan penulis hadits bekerja. Karya buku-buku tafsir dari ulama yang hidup pada zaman Abbasiyah adalah kitab al Jami' al Bayan yang ditulis at Tabari $(225 \mathrm{H} / 839$ M-310 H/923 M), al Kasysyaf oleh az Zamakhsyari (467 H/1075 M-538 H/1144 M), dan Mafatih al Gaib oleh Fakhruddin ar Razi $(543$ H/1149 M-606 H/1189 M). Disamping itu para ulama juga mengumpulkan Hadits, seperti; al Musnad oleh Ahmad bin Hambal (w. 241 H/885 M). Pengumpulan enam kitab yang dikenal al Kutub as Sittah dipelopori oleh Bukhori (256 H/870 M), Muslim (261 H/875 M), Abu Daud (275 H/888 M), at Tirmizi (279 H/892 M), an Nisa'i (303 H/915 M), dan Ibnu Majah (273 H/886 M) (Lubis, tt: 103).

Tradisi berdiskusi juga telah berkembang, adanya Bayt al Hikmah sebagai tempat berkumpul untuk bertukar pikiran dan berdebat masalah keilmuan membantu dalam menciptakan suasana keilmuan yang kondusif (Hasan, 1989: 133). Dari diskusi, maka munculah berbagai pemikiran kreatif sampai kepada aliran-aliran pemikiran. Aliran-aliran teologi sudah ada pada masa Bani Umayyah, seperti Khawarij, Murjiah dan Mu'tazilah. Akan tetapi perkembangan pemikirannya masih terbatas. Teologi rasional Mu'tazilah muncul di ujung pemerintahan Bani Umayyah. Namun, pemikiran-pemikirannya yang lebih kompleks dan sempurna baru dirumuskan pada masa pemerintahan Bani Abbas periode pertama, setelah terjadi kontak dengan pemikiran Yunani yang membawa pemikiran rasional dalam Islam.

Perkembangan ilmu-ilmu umum bisa dilihat dari, misalnya: ilmu kedokteran (at Tibb) dengan didukung adanya sekolah khusus kedokteran di Jundishapur. Ilmu matematika, astronomi dikembangkan dengan fasilitas didirikannya observatorium pada masa khalifah al Ma'mun di Sinjar. Dengan adanya observatorium itu menunjukan adanya tradisi penelitian atau eksperimen yang tinggi di bidang ilmu eksak. Tradisi ini juga berkembang pada penelitian Hadits sehingga muncul berbagai kitab Hadits. Dalam bidang astronomi terkenal nama al Fazari sebagai astronom Islam yang pertama kali menyusun astrolobe. Al Fargani, yang dikenal di Eropa dengan nama al Faragnus, menulis ringkasan ilmu astronomi yang diterjemahkan ke dalam bahasa Latin oleh Gerard Cremona dan Johannes Hispalensis. 
Bidang kedokteran dikenal nama al Razi dan Ibnu Sina. Al Razi adalah tokoh pertama yang membedakan antara penyakit cacar dengan measles. Dia juga orang pertama yang menyusun buku mengenai kedokteran anak. Sesudahnya, ilmu kedokteraan berada di tangan Ibnu Sina. Ibnu Sina yang juga seorang filosof berhasil menemukan sistem peredaran darah pada manusia. Diantara karyanya adalah al Qoonuun fi al Thibb yang merupakan ensiklopedi kedokteran paling besar dalam sejarah. Minat orang Arab terhadap ilmu kedokteran diilhami oleh Hadits Nabi yang membagi pengetahuan kedalam kelompok teologi dan kedokteran. Dengan demikian, seorang dokter sekaligus merupakan seorang ahli metafisika, filosofis, dan sufi.

Bidang optikal Abu Ali al Hasan Ibnu al Haythami, yang di Eropa dikenal dengan nama Alhazen, terkenal sebagai orang yang menentang pendapat bahwa mata mengirim cahaya ke benda yang dilihat. Menurut teorinya yang kemudian terbukti kebenarannya bendalah yang mengirim cahaya ke mata. Di bidang kimia, terkenal nama Jabir Ibnu Hayyan. Dia berpendapat bahwa logam seperti timah, besi dan tembaga dapat diubah menjadi emas atau perak dengan mencampurkan suatu zat tertentu. Ia merupakan tokoh terbesar dalam bidang ilmu kimia pada abad pertengahan. Sebuah legenda menyebutkan bahwa putra mahkota Dinasti Umayyah, Khalid Ibnu Yazid ibn Mu'awiyah dan Imam Syiah ke-4, Ja'far al Shadiq dari Madinah, pernah menjadi gurunya. Ia telah mengakui dan menyatakan pentingnya eksperimen secara seksama daripada ahli kimia sebelumnya, dan telah melangkah lebih maju baik dalam perumusan teori maupun dalam praktik kimia. Karyakaryanya, seperti, Kitab al Rahmah (Buku Cinta), Kitab al Tajmi (Buku tentang konsentrasi), al Zi'baq al Syarqi (Air Raksa Timur) telah diterbitkan. Jabir menggambarkan secara ilmiah dua operasi utama kimia: kalnikasi dan reduksi kimiawi. Ia memperbaiki berbagai metode penguapan, sublimasi, peleburan, dan kristalisasi. Secara umum, Jabir memodifikasi teori Aristotelian tentang unsur pembentuk logam yang tetap menjadi rujukan penting dengan beberap perubahan kecil sempai era kimia modern pada abad ke-18.

Tokoh penting pertama dalam zoology dan antropologi adalah Abu Utsman Amr Ibnu Bahr al Jahiz yang hidup di Basrah. Karyanya, Kitab al 
Hayawan (buku tentang hewan), lebih bersifat teologis dan folklore, tidak bernuansa biologis. Karya ini, yang di dalamnya mengutip gagasan Aristoteles, memuat satu bahasan yang menjadi cikal bakal lahirnya teori evolusi, adaptasi dan psikologi hewan. Al Jahiz tahu bagaimana memperoleh ammonia dari organ bagian dalam hewan melalui penyulingan. Di bidang matematika terkenal nama Muhammad Ibnu Musa al Khawarizmi, yang juga mahir dalam bidang astronomi. Dialah yang menciptakan ilmu aljabar. Kata "aljabar" berasal dari judul bukunya, Al Jabr wa al Muqoibalah.

Dalam bidang sejarah Islam terkenal nama at Tabari, al Birudin dan al Mas'udi. Al Mas'udi juga dikenal sebagai ahli dalam ilmu geografi. Di antara karyanya adalah Muuruj al Zahab wa Ma'aadzin al Jawahir. Sebagain besar sejarawan periode Abbasiyah mempelajari dan menulis tentang sejarah hidup (sirah) Nabi SAW. Salah satu sirah yang ada adalah yang ditulis oleh Muhammad bin Ishaq (w. 150 H/767 M) (Lubis, tt: 104).

Tokoh-tokoh terkenal dalam bidang filsafat, antara lain al Farabi, Ibnu Sina, dan Ibn Rusyd. Al Farabi banyak menulis buku tentang filsafat, logika, jiwa, kenegaraan, etika, dan interpretasi terhadap filsafat Aristoteles. Ibn Sina juga banyak mengarang buku tentang filsafat. Yang terkenal diantaranya ialah al Syifa'. Ibnu Rusyd yang di Barat lebih dikenal dengan nama Averroes, banyak berpengaruh di Barat dalam bidang filsafat, sehingga di sana terdapat aliran yang disebut dengan Averroisme.Penerjemahan buku-buku asing marak dilakukan pada masa ini, tidak saja karya orang Nestoris dan aliran Neoplatonis dari Mesopotania juga banyak, bahkan khalifah juga berusaha untuk membeli berbagai karya ilmiah klasik dari kalangan manapun dan dari bahasa manapun termasuk bahasa Yunani, Persia dan lainya, termasuk musuh politik mereka sekalipun, jika tidak memperoleh manuskrip dengan penaklukan. Perhatian masyarakat sangat tinggi dibidang sastra, bisa dikatakan pada abad ini adalah abad keemasan sastra Arab dan sejarah. Masyarakat Arab sangat membanggakan sastra dan asal usul mereka, dalam periode awal Abbasiyah telah didapati banyak terjemahan dari bahasa Pahleli atau adaptasi dari bahasa persia (Montgomery, 1990: 189). Banyak orang-orang yang gemar untuk menulis sastra dan sejarah kabilah-kabilah mereka, kehebatan nenek 
moyang meraka sangat dibanggakan. Bagian sejarah yang penting adalah riwayat Nabi Muhammad SAW.

Berkembanganya pemikiran intelektual dan keagamaan pada periode ini (Abbasiyah) antara lain karena kesiapan umat Islam untuk menyerap budaya dan khazanah peradaban besar dan mengembangkannya secara kreatif, ditambah dengan dukungan dari khalifah pada waktu itu dengan memfasilitasi terciptanya iklim intelektual yang kondusi. Sumbangsih pada era ini, didukung sikap umat Islam yang terbuka terhadap seluruh umat manusia yang datang berinteraksi dengan mereka, hal inilah menimbulkan simpati dan mendorong orang-orang non arab (mawali) untuk masuk Islam (Montgomery, 1990: 103). Kelompok ini ikut memberi sumbangan besar bagi kemajuan paradaban pada masa ini. Para ilmuan pada masa ini menduduki posisi penting.

\section{Latar belakang Berdirinya Bayt al Hikmah}

Pada masa daulah Abbasiyah, ibukota Bagdad menjadi pusat intelektual muslim, di mana terjadi pengembangan ilmu pengetahuan dan kebudayaan Islam. Perpustakaan adalah salah satu cara yang ditempuh oleh orang dahulu untuk menyiarkan ilmu pengetahuan. Pada masa itu buku-buku sulit untuk dimiliki karena belum ada mesin percetakan sehingga penyebarannya masih melalui tulisan tangan. Sehingga wajar buku-buku yang ada hanya dimiliki atau mampu dibeli oleh golongan kaya atau yang memilki kemauan keras untuk menuntut ilmu pengetahuan. Oleh kerena itu keberadaan perpustakaan sangat menolong dan bermanfaat bagi orang-orang yang ingin menggali maupun menyebarkan ilmu pengetahuan.

Berbagai buku dikumpulkan diperpustakaan dan dibuka untuk umum. Dalam peradaban yang tinggi untuk ukuran saat itu, buku-buku mempunyai nilai moril yang sangat tinggi. Keberadaan buku dimuliakan, pengahargaan mereka terhadap buku-buku menjadikan mereka sangat mendukung pendirian dan keberadaan perpustakaan (Salabi, 1987: 115, 117, 120). Banyak perpustakaan yang tidak hanya didirikan di tempat-tempat umum oleh penguasa (khalifah), tetapi juga di rumah-rumah para pembesar dan orang 
kaya, karena bagaimanapun keberadaanya perpustakaan akan menjadi rumah itu lebih baik bersemarak dan tuan rumahnya menjadi orang terpandang dan mulia. Tersedianya berbagai buku serta kajian ilmiah yang dilakukan dalam perpustakaan tersebut telah menjadi salah satu bibit tumbuhnya lembaga tinggi Islam yang pertama, seperti Akademi Bayt al Hikmah di Bagdad dan Akademi Dar al Hikmah dengan Cairo (Salabi, 1987: 115). Jadi keberadaan perpustakaan dalam tradisi keilmuan Islam, mempunyai peran bukan saja sebagai sarana peminjaman buku, namun sebagai pusat pengembangan ilmu pengetahuan. Hal ini juga yang terjadi pada perpustakaan Bayt al Hikmah yang disamping berfungsi sabagai perpustakaan untuk merangsang gerakan penerjemahan karya-karya logika, keilmuan dan filsafat dalam bahasa Arab juga telah menjadi pusat transmisi keilmuan pada masa daulah Abbasiyah.

Menurut Ibnu al Nadhim, Bayt al Hikmah dibangan pada masa Khalifah Harun al Rasyaid dan dilanjutkan pada masa Khalifah al Amin untuk kemudian direnovasi kembali oleh Khalifah al Ma'mun pada tahun 217/832 M dengan biaya sebesar satu juta dolar (Nakosteen, 1996: 287). Hal ini ditunjukan dengan adanya 'Abu Sahl al Fadl bin Naubakhat yang bertugas menerjemahkan buku-buku asing, yaitu dari buku-buku yang ditulis kedalam Persi ke dalam bahasa Arab di Khazanah al Hikmah pada masa Harun al Rasyid dan 'Allan al Syu'ubi asal Persia yang bertugas menulis buku-buku pada masa Khalifah Harun al Rasyid, al Ma'mun dan keluarga al Baramikah (Lapidus, 1999: 110).

\section{Faktor-Faktor Pendorong Perkembangan Bayt al Hikmah}

Keberadaan Bayt al Hikmah yang membawa dunia intelektual Islam menuju masa kejayaan dan keemasan abad tengah, tentu saja telah mengundang minat para ahli untuk menganalisa dan mempelajari kondisi-kondisi internal sebagai faktor penyebab kemajuan perkembangannya. Di sini dapat dikemukakan beberapa faktor pendorong perkembangan Bayt al Hikmah tersebut, baik yang bersifat intern maupun ekstern.

Faktor-faktor intern yang dimaksud adalah:

1. Terciptanya stabilitas politik, kemakmuran ekonomi dan adanya dukungan 
dari khalifah Abbasiyah, karena mempunyai kecenderungan kepada ilmu pengetahuan, sebagai pendorong utama laju berkembangnya lembaga Bayt al Hikmah sejak masa khalifah al Ma'mun. Khalifah ini selalu berupaya mendukung kegiatan Bayt al Hikmah, seperti memberi penghargan tinggi bagi sarjana-sarjana yang mempunyai reputasi yang tinggi dan bidangnya. Ia telah memberikan gaji yang cukup tinggi kepada para penerjamah yang ditugaskan di Bayt al Hikmah.

2. Adanya kebebasan keintektualan dan interaksi positif antara orangorang Arab Muslim dan non-Muslim, serta toleransi dan suasana penuh keterbukaan.

3. Adanya respon umat Islam terhadap usaha pengembangan Ilmu pengetahuan yang diikuti dengan adanya semangat keagamaan dan disertai pemikiran yang rasional.

4. Menurut Azzumardi Azra dalam bukunya; Esei-esei Intelektual Muslim dan Pendidikan Islam Tinggi yang mengatakan:

"Kemajuan pendidikan seperti yang ada di Bayt al Hikmah ini, disamping didorong ajaran-ajarannya Islam yang menuntut penganutnya untuk mengembangkan ilmu pengetahuan,juga karena kemampuan masyarakat mewujudkan situasi keilmuan yang dinamis. Pendidikan tinggi Islam tidak bersifat eksklusif, ia terbuka terhadap pikiran-pikiran non-muslim. Objektifitas keilmuan yang direfleksikan dengan penerimaan diktum-diktum ilmiah secra kritis melalui perdebatan-perdebatan intelektual meratakan jalan bagi kemajuan pikiran Islam.

Pendidikan tinggi Islam sebagai pusat intelektual tidak berubah menjadi "menara gading" yang steril dan terasing dari lingkungan masyarakatnya. Ia responsif terhadap perubahan-perubahan yang terjadi di lingkungan yang mengitarinya. Sebagaimana terlihat, ia terbuka bagi setiap pencinta ilmu, tanpa dibarengi oleh birokrasi-birokrasi dan formalitas yang ketat" (Azra, 1998: 105).

5. Adanya pertentangan di kalangan kaum muslimin sendiri dan terpecahnya mereka menjadi golongan-golongan, di mana tiap-tiap golongan berusaha untuk mempertahankan wujud dirinya, dan memerlukan bahan-bahan perdebatan. Hal ini terjadi antara Mu'tazilah dan golongan Ahlu Sunnah wal Jama'ah (Hanafi, 1990: 41). 
6. Situasi politik saat itu, dimana setiap tokoh yang berkuasa harus bisa mengambil hati rakyatnya agar tetap menaruh simpati pada pemimpinnya. Itulah para khalifah Abbasiyah telah mengalihkan perhatian rakyat pada pentingnya ilmu pengetahuan yang memang begitu diminati masyarakat Arab pada waktu itu.

7. Terpadunya peranan Bayt al Hikmah sebagai lembaga penerjemahan, akademi, perpustakaan dan observatorium, menyebabkan lembaga tersebut dapat mengoptimalkan perannya dalam transmisi ilmu pengetahuan.

Sedangkan beberapa faktor intern yang berperan besar dalam pendirian dan pengembangan Bayt al Hikmah ini adalah:

1. Adanya kesepakatan antara Kaisar Romawi dan Khalifah al Ma'mun yang isinya telah memperkenankan kepada khalifah al ma'mun untuk menjalin berbagai buku langka peninggalan Yunani kono yang ada di wilayah imperium Romawi dan membawa buku-buku tersebut ke Bayt al Hikmah di Bagdad.

2. Kesediaan orang-orang Kristen Nestorius untuk bekerja di Bayt al Hikmah dan membantu khalifah dalam menerjemahkan buku-buku asing tersebut ke dalam bahasa Arab seperti yang telah dilakukan oleh Hunain bin Ishaq dan murid-muridnya.

3. Muncul dan berkembangnya pemikiran Yunani dan Persia yang sangat mempengaruhi model pemerintahan khalifah Abbasiyah (Mahmudunnasir, 1991: 248). Sebab pemikiran tersebut sangat mendukung untuk mmeperkenalkan idealnya manusia mengenai pengukuhan diri kalangan aristokrasi. Seorang aristokrat haruslah seorang yang menguasai berbagai bidang pengetahuan, kepustakaan, sejarah, filsafat, dan agama (Lapidus, 1999: 114).

\section{Keunggulan Bayt al Hikmah}

Koleksi yang dimiliki oleh Bayt al Hikmah cukup lengkap mulai dari buku-buku agama Islam (kitab-kitab tafsir, Hadits al-Kutub as Sittah, teologi sampai kepada buku sains; astronomi, matematika, sejarah, kedokteran (Al Hawi oleh Muhammada bin Zakaria, Ali Abbas dengan kitab al Maliki, Ibnu Sina dengan al Qanun fi at Tibb dan 
sebagainya) ditambah lagi dengan kitab-kitab sastra dan buku-buku yang dihadirkan dari hasil terjemahan. Koleksi yang dimiliki tidak kurang dari 100.000 volume, boleh jadi sebanyak 600.000 jilid buku, termasuk 2.400 buah al Quran berhiaskan emas dan perak disimpah diruang terpisah (Nakosteen, 1996: 95).

Buku-buku lainya tentang ilmu-ilmu hukum (fiqih), tata bahasa, retorika, sejarah, biografi, astronomi, dan ilmu kimia tersimpan dalam rak (peti) buku yang luas di sekitar (sepanjang) dinding, yang terbagi dalam susunan di atas rak-rak buku, masing-masing memiliki satu pintu dengan sebuah kunci. Di atas pintu masing-masing bagian, tergantung satu daftar buku-buku yang ada di dalamnya, demikian pula peringatan (keterangan) tentang buku-buku yang tidak ada dari masing-masing cabang ilmu pengetahuan (Cyril Elgood dalam Nakosteen, 1996: 95).

Bayt al Hikmah bukan hanya sekedar sebagai perpustakaan saja dengan koleksi bukunya, tetapi ia berfungsi sebagai lembaga penerbitan dan lembaga penerjemahan, yang tentunya dari berbagai buku yang di terjemahkan tanpa melihat latar belakangnya dan hal ini mendapat dukungan yang tinggi dari khalifah pada waktu itu dengan menunjuk orang sebagai penerjemah dan sampai kepada pembelian buku dari daerah lain jika daerah itu belum di taklukan oleh khalifah. Di samping itu Bayt al Hikmah juga berfungsi sebagai observatorium, tempat untuk melakukan eksperimen, dan juga sebagai tempat berkumpul untuk berdiskusi, sehingga dari hasil diskusi dan penelitian ini maka akan menghasilkan ilmu baru dan nantinya akan di terbitkan menjadi buku.

\section{Membangun (Peradaban) Tradisi Keilmuan Islam}

Jika kita perhatikan masa kejayaan Islam (Abbasiyah), tentunya hal yang menarik kita perhatikan adalah tingginya tradisi keilmuan masyarakat. Tradisi yang berkembang pada waktu itu adalah tradisi membaca, menulis, berdiskusi, keterbukaan atau kebebasan berfikir, penelitian serta pengabdian mereka akan keilmuan yang meraka kuasai.

Tradisi intelektual terlihat dari kecintaan mereka terhadap buku-buku. 
Hal tersebut dibarengi dengan adanya perpustakaan-perpustakaan baik atas nama pribadi yang diperuntukkan untuk khalayak umum atau yang disponsori oleh khalifah. Para ulama sengaja open house bagi siapa aja yang datang kerumahnya untuk membaca (mencari ilmu). Kedudukan meraka juga dimata masyarakat sangat mulia. Sedemikian cintanya masyarakat kapada ilmu sampai-sampai khalifah pada waktu itu, untuk merebut hati masyarakat harus memberi perhatian kepada pengembangan ilmu, jadi tidak heran khalifah mendirikan perpustakaan dan beberapa penghargaan bagi ulama atau orang-orang yang berhasil menemukan keilmuan baru.

Hasil membaca kemudian didiskusikan dan kembangkan lagi, meraka menjadikan perpustakaan dan masjid sebagai tempat berdiskusi, dari sinilah memunculkan ide atau keilmuan baru, tercipta tradisi menulis, menyadarkan kebutuhan untuk berkarya yang sangat tinggi, sehingga kita bisa menikmati hasilnya dari karya-karya mereka.

Tradisi penelitian juga kita lihat dari temuan-temuan (eksperimen) ilmu dalam bidang sains seperti matematika, kedokteran, astronomi, dan lainnya. Hal ini juga kita bisa dilihat dari adanya observatorium yang berada di Sinjar pada khalifah al Ma'mun, atau adanya sekolah khusus kedokteran di Jundishapur. Penelitian akan Hadits dan lain sebagainya. Itulah keingintahuan meraka yang sangat tinggi bukan hanya keilmuan yang bernuansa keislaman tapi juga bernuansa ilmu umum dan alam.

Kebebasan, keterbukaan berpikir dan kecintaan ilmu memotivasi kegiatan penerjemahan pada waktu itu tanpa memandang dari mana buku itu dan siapa pengarangnya. Mereka tidak melihat lagi latar belakang agama, maupun bangsa, justru meraka bisa kerjasama dalam keilmuan dengan bangsa lain atau orang-orang non Islam tanpa sedikitpun takut akan hilang atau rusaknya akidah meraka. Tradisi yang sama juga telah berkembang di tradisi keilmuan barat. Motivasi mereka sangat tinggi untuk mencari ilmu, tradisi membaca dan berdiskusi tinggi, tradisi meneliti yang tinggi, keterbukaan berfikir dan kebutuhan untuk berkarya juga sangat tinggi. Teknologi dan informasi kebanyakan dikuasai oleh Barat, banyak temuan dan peraih nobel pengetahuan bukan dari kalangan Islam. Hal-hal seperti itulah, menurut 
penulis kemajuan Barat dan Islam Abbasiyah dalam hal ilmu pengetahuan yang perlu kita kembangkan untuk kemajuan dibidang pendidikan Islam.

\section{Simpulan}

Pada masa Abbasyah Islam meraih kejayaanya. Banyak kontribusi ke-ilmuan yang disumbangkan. Karya dan tokoh-tokohnya telah menjadi inspirasi dalam pengembangan keilmuan, oleh karena itu masa ini dikatakan sebagai masa keemasan Islam walau akhirnya peradaban Islam mengalami kemunduran dan kehancuran di bidang keilmuan bersamaan dengan berakhirnya pemerintahan Abbasiyah. Peran Bayt al Hikmah yaitu memiliki koleksi buku 100.000 volume, terdiri dari 600.000 buku dan 2.400 buah al Quran berhiaskan emas dan perak, selain itu Bayt al Hikmah bukan hanya sebagai perpustakaan tetapi juga lembaga penerbitan dan lembaga penerjemah. Peran tersebut muncul karena dipengaruhi oleh tradisi intelektual yang ditandai adanya perpustakaan-perpustakaan baik atas nama pribadi atau umum. Dari kajian ini, diharapkan mampu menyadarkan kita akan pentingnya lingkungan intelektual yang kondusif dan memotivasi untuk mencari ilmu. Belajar sejarah akan tidak ada gunanya jika kita tidak bisa mengambil pelajaran darinya.

\section{Daftar Pustaka}

Ahmad Fadhil, Lubis Nur. Ensiklopedi Tematis dunia Islam (Khilafah). Jakarta: Ikhtiayas Baru Van Hoeve.

Amin, Mansur. 2004. Sejarah Peradaban Islam. Bandung: Indonesia Spirit Faoundation.

Azra, Azumardi. 1998. Esei-eseiIntelektual Muslim dan Pendidikan Islam. Jakarta: Logos.

Hanafi, Ahmad. 1990. Pengantar Filsafat Islam. Jakarta: Bulan Bintang.

Hasan, Ibrahim. 1989. Sejarah dan Kebudayaan Islam (Islamic History and Culture). Terjemahan oleh Djahdan Humam. Yogyakarta: Tiara Wacana. 
Joesoef, Sou'yb. 1977. Sejarah Daulah Abasiyah I. Jakarta: Bulan Bintang.

Langgulung, Hasan. 2004. Manusia Dan pendidikan; Suatu Analisa Psikologis, filsafat dan Pendidikan. Jakarta: Al Husna Baru.

Lapidus, Ira M. 1999. Sejarah Sosial Umat Islam (A-History of Islamic Societies). Terjemahan oleh Ghufron A. Mas'adi. Jakarta: Raja Grafindo Persada.

Mahmudunnasir, Syed. 1991. Islam Konsepsi dan Sejarahnya. Bandung: Rosda Karya.

Maryam, Siti, (Ed.). 2003. Sejarah Peradaban Islam; dari Masa Klasik Hingga Modern. Yogyakarta: LESFI.

Nakosteen, Mehdi. 1996. Kontribusi Islam atas Dunia Intelektual Barat; Deskripsi Analisis abad keemasan Islam. Surabaya: Risalah Gusti.

Salabi, Ahmad. 1987. Tarikh al Tarbiyah al Islamiayah. Al Misriyah: Maktabah al Nadhaoh.

Watt W. Montgomery. 1990. Kejayaan Islam; Kajian kritis dari Tokoh Orientalis. Yogjakarta: Tiara Wacana.

Zuhairini. dkk. 1997. Sejarah Pendidikan Islam. Jakarta: Bumi Aksara. 